\title{
A synesis mint politikai fogalom Aristotelésnél
}

\section{Összefoglalás:}

A Nikomachosi etika hatodik könyve szerint a phronésis (gyakorlati bölcsesség) legfontosabb feladata annak megfontolása, hogy mi válik javára az egyes embernek az egészében vett ,jó élet” szempontjából. Ugyanakkor ennek a megfontolásnak nemcsak az egyéni, hanem a közösségi élet is tárgya: a gyakorlati bölcsesség politikai erény is. Dolgozatom fö tétele az, hogy a phronésis közösségi (és így politikai) dimenzióját az a gondolkodásbéli erény nyitja meg, amelyet Aristotelés synesisnek nevez (megértés, értelmesség). A synesis ilyen módon a phronésis politikai alkalmazásának fontos eszköze lesz (EN VI. 11-12. 1142b34-1143a32). Tételemet két olyan szöveghely értelmezésével támasztom alá, ahol a synesis már nyilvánvalóan politikai összefüggésben jelenik meg: a törvényhozás (EN X. 10. 1181a18) és a politikai deliberáció (Pol. IV. 4. 1291a28) kontextusában.

\section{Kulcsszavak:}

synesis, megértés/értelmesség, gyakorlati bölcsesség, politika, törvényhozás, megfontolás

\begin{abstract}
:
According to Book 6 of the Nicomachean Ethics, the primary task of phronēsis (practical wisdom) is to deliberate about the things that are good in general for each person. However, phronessis concerns not only individuals but also the community: practical wisdom is a political virtue as well. In my paper, I argue that the intellectual excellence called sunesis (comprehension) by Aristotle opens up the social dimension of practical wisdom, and thus provides an important means for the political application of phronēsis (EN 6 . 1142b34-1143a32). To support my argument I interpret two further passages where sunesis appears in a clearly political context: in relation to legislation (EN 10. 1181a18) and to political deliberation (Pol. 4. 1291a28).
\end{abstract}

\section{Keywords:}

sunesis, comprehension, practical wisdom, politics, legislation, deliberation

Aristotelés ${ }^{1}$ a phronésis tárgyalása során a következőképpen fogalmaz: „A politikai tudás és a gyakorlati bölcsesség ugyanaz a beállítódás, mibenlétüket tekintve azonban nem ugyanazok.”’2 A ,mibenlétüket tekintve ... nem ugyanazok ( gyakran előfordul Aristotelés szövegeiben, és arra az esetre utal, amikor ugyanarra a dologra két különböző fogalom vonatkozik, melyeknek terjedelme (extenziója) azonos, ám jelentésük (intenziójuk) különböző, s így az adott dolog különböző aspektusait fejezik ki (lásd pl. EN I.

\footnotetext{
${ }^{1}$ E tanulmány korábbi, angol nyelvủ változatát 2012. novemberében a PPKE Bölcsészettudományi Karán a „Political Aristotelianism” címü nemzetközi tanácskozáson adtam elö, a magyar változatot pedig 2014. novemberében, az ELTE Bölcsészettudományi Karának Filozófiatörténeti Fórumán mutattam be. Mindkét alkalom résztvevőinek sokkal tartozom kritikai megjegyzéseikért, s különösen is hálás vagyok Németh Attilának és Bene Lászlónak írásban is elküldött észrevételeikért. A tanulmány a DAAD és a Bolyai János Ösztöndíj támogatásával készült.

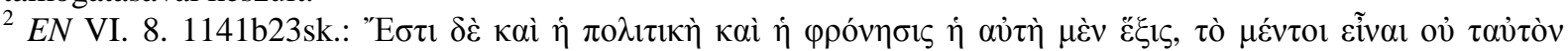

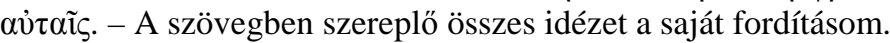


13. 1102a30, V. 3. 1130a10-13; DA II. 12. 424a25-28, III. 2. 427a2sk.; Metaph. XII. 10. 1075b4-6). ${ }^{3}$ Ennek értelmében a politikai tudás (politiké) és a gyakorlati bölcsesség (phronésis), ha beállítódásként (hexisként) vesszük őket, akkor ugyanazok, miközben „mibenlétük” és így müködésük, vagyis az a terület, amelyen alkalmazzuk őket, különböző lehet. Ugyanazon képesség különböző megnyilvánulásairól van tehát szó, ${ }^{4}$ melyeket ennek megfelelően különböző viszonylatokban alkalmazunk. ${ }^{5}$ A hétköznapi felfogás szerint a phronésis az egyének gyakorlati ügyeire vonatkozik (Aristotelésnél a „gyakorlati” azt jelenti: a cselekvéssel, a praxisszal kapcsolatos, vagyis erkölcsi-politikai ügyekröl van szó), miközben a politikének a politikai közösség gyakorlati ügyeivel van dolga (EN VI. 9. 1141b29-33). Valójában azonban a phronésis mindkét területet átfogja, és a működését vezérlő legfőbb kérdés is ugyanaz mindkét területen: mi a jó egy individuum, illetve egy közösség mint individuumok csoportja számára (1141b33-1142a10). ${ }^{6}$ A phronésis a léleknek egy és ugyanaz a beállítódása, akár a gyakorlati bölcsességgel rendelkező egyén boldogságára vonatkozik, akár politikai tudásként az egész polisz boldogságára irányul. ${ }^{7}$ A politikai tudást úgy határozhatjuk meg, „,mint a politikai szférában müködtetett gyakorlati tudást.”8 Az olyan embereket, mint Periklés, azért tekinthetjük bölcsnek (phronimosnak), mert képesek fölismerni azt, hogy mi a jó nekik maguknak és másoknak is, vagyis a phronésis egyéni és közösségi működtetésébent egyaránt kiválóak (vö. EN VI. 5. 1140b7-10).

Mindazonáltal a phronésis individuális és politikai müködése különbözik egymástól. Az előbbi esetben a lényeg a saját érdekünk, a saját boldogságunk vagy jóllétünk, és amire itt a megfontolás (buleusis) vonatkozik, az saját valódi érdekeink fölismerése és szem előtt tartása, mindvégig ennek a „sajátosan a cselekvőre összpontosító (agent-focused)" deliberációnak a folyamatában. ${ }^{9}$ Az utóbbi esetben viszont különböző emberek érdekeit kell egyidejűleg tekintetbe vennünk, és olyan döntésre jutnunk, amely mindannyiuk jólétét

\footnotetext{
${ }^{3}$ Vö. Wolf magyarázatát $E N$ V. 3. 1130a11-14-hez a ,jóság”, ,jónak lenni” és az „igazságosság”, ,igazságosnak lenni” fogalma kapcsán: „Die beiden Begriffe haben dieselbe Extension, denselben Umfang, aber nicht dieselbe Intension, nicht denselben Sinn. Das Sein, welches nicht dasselbe ist, ist dasjenige, das in einer Definitionsaussage »A ist B « vorkommt, die das Wesen einer Sache bestimmt. Gemeint ist also, wenn man den Satz expliziter formuliert: »Sie sind faktisch dieselbe Disposition, aber was es heißt, Gutheit zu sein, ist nicht identisch mit dem, was es heißt, Gerechtigkeit zu sein. «" Aristoteles: Nikomachische Ethik. Übersetzt und herausgegeben von $U$. Wolf. Hamburg 2006. 368.

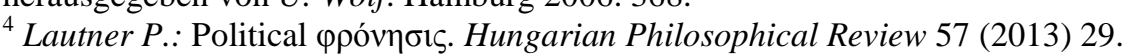

${ }^{5}$ J. M. Cooper: Reason and Human Good in Aristotle. Cambridge (Massachusetts) - London 1975. 34sk.

${ }^{6}$ Vö. C. D. C. Reeve: Aristotle on Practical Wisdom. Nicomachean Ethics VI. Translated with Introduction, Analysis, and Commentary. Cambridge (Massachusetts) - London 2013. 67; vö. még EN I. 1. 1094a18-28; EE I. 8. 1218b11-14.

${ }^{7}$ C. D. C. Reeve: Action, Contemplation, and Happiness. An Essay on Aristotle. Cambridge (Massachusetts) London 2012. 151.

${ }^{8}$ M. Schofield: Aristotle's Political Ethics. In: The Blackwell Guide to Aristotle's Nicomachean Ethics. Ed. $R$. Kraut. Malden - Oxford - Carlton 2006. 318.

${ }^{9}$ Reeve: i. m. (6. jegyz.) 195.
} 
előmozdítja, vagyis amely lehetőség szerint az egész közösség jólétét szolgálja. Ennek értelmében az első esetben a deliberáció döntően egyéni jellegű, s közvetlenül ránk vonatkozik, míg a második esetben nemcsak a megfontolás célja, hanem folyamata is közösségi jellegü, mely a különböző vélekedésekkel, érdekekkel és motivációkkal rendelkező emberek dialogikus közösségében megy végbe. ${ }^{10}$

Ezen a ponton a következő kérdés merül föl: mi teszi lehetővé azt, hogy a phronésis interperszonális, sőt dialogikus karakterrel rendelkezzen, nemcsak abban az értelemben, amely Platónnál és Aristotelésnél is releváns, vagyis hogy a gondolkodás már önmagában véve is dialogikus, hanem abban az értelemben is, hogy a phronésis különbözö emberek között lezajló, valóságos dialógus folyamatában fejtse ki működését? Melyik az a képességünk, amely segítségünkre van abban, hogy mások helyzetét, gyakorlati érdekeit és megfontolásait mi magunk is fontolóra vegyük, s hogy ezeket közös célokra vonatkoztassuk? Aristotelés nem ad explicit választ ezekre a kérdésekre. Úgy tünik, nem szentel figyelmet ennek a problémának, sőt, maguk a kérdések sem jelennek meg a szövegeiben. (Ugyanakkor biztosra veszi például azt, hogy ha a megfontolás folyamatában többen vesznek részt, akkor ez jobb eredményhez fog vezetni: lásd pl. Pol. IV. 15. 1286a26-35.) Ennek ellenére úgy vélem, hogy a kérdésre kinyerhető egyfajta válasz gyakorlati filozófiai műveiből. Néhány megfogalmazása ugyanis mintha arra utalna, hogy ez a képesség az, amelyet ő synesisnek vagyis „értelmességnek”, „felfogásnak”, „megértésnek” - nevez. Úgy tünik, a synesis biztosítja azt az eszközt, amelynek segítségével a phronésis, vagy pontosabban ennek müködése, a megfontolás/deliberáció (buleusis) nemcsak az egyes individuumokra, hanem más individuumokra vagy az általuk alkotott közösségre is vonatkozhat.

A synesis politikai szerepe mellett három lépésben fogok érvelni. Első lépésként két olyan passzust értelmezek a Nikomachosi etika hatodik könyvéböl, amelyekben Aristotelés a synesisnek mint a phronésis egy dimenziójának a legrészletesebb magyarázatát adja. Ez után, második lépésként, összefoglalom azokat a tanulságokat, amelyek a synesis szó és fogalom történetéből adódnak, s amely tanulságok véleményem szerint megerősítik állításomat. Ehhez

\footnotetext{
${ }^{10}$ Amint az köztudomású, Aristotelésnél nem húzódik éles határvonal etika és politika között: „ethics is politics for the individual; political science, ethics for the city or state" (C. D. C. Reeve: Aristotle on the Virtues of Thought. In: Kraut (ed.): i. m. [8. jegyz.] 210; vö. Reeve: i. m. [6. jegyz.] 191, 198; uö: Practices of Reason. Aristotle's Nicomachean Ethics. Oxford 1995. 76, 80, és EN VI. 9. 1142a9sk.). Ugyanakkor az EN VI. 8. 1141b24-33-ban Aristotelés különbséget tesz azok között a területek és azok között a módok között, amelyeken és ahogyan a phronésis müködik. (Ennek a különbségtételnek a jelentőségéről etika és politika viszonyának szempontjából lásd P. A. Vander Waerdt: The Political Intention of Aristotle's Moral Philosophy. AncPhil 5 [1985] 82-85, Bodéüs [R. Bodéüs: The Political Dimensions of Aristotle's Ethics. Albany 1993.] felfogását kritizálva.) Ahogyan Reeve: i. m. (1995) 80 megfogalmazza: ,we can continue to think of phronessis as being primarily concerned with the individual's own eudaimonia provided that we do not conceive of that concern as narrowly focused on himself to the exclusion of others."
} 
kapcsolódóan a Nikomachosi etika nyolcadik könyvének egy szakasza alapján megpróbálom megmutatni, hogy a synesis személyközi vagy társas jelentése Aristotelés számára is eleven volt. A harmadik lépésben két további szöveghelyet értelmezek a Nikomachosi etikából és a Politikából, ahol a synesis immár explicit módon politikai összefüggésben kerül elő. Amellett fogok érvelni, hogy a synesis ezekben a szakaszokban nem akármilyen „megértést”, „felfogást” vagy megkülönböztetés nélkül vett „,megismerést” jelent, hanem sokkal inkább úgy értelmezhető, mint egy olyan sajátos „,megértés” vagy „értelmesség”, amely kifejezetten a politika és a jog területén müködik. Végül dolgozatom negyedik részében összefoglalom vizsgálódásaim eredményét.

Aristotelés a Nikomachosi etika hatodik könyvében részletesen magyarázza a synesis jelentését és funkcióját:

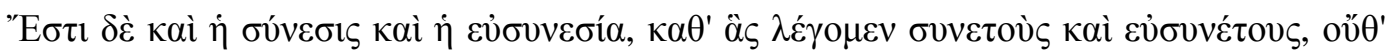

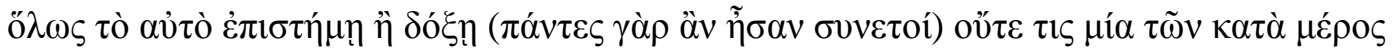

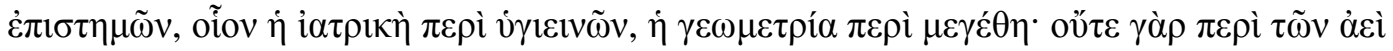

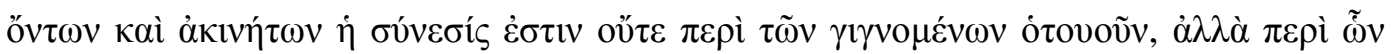

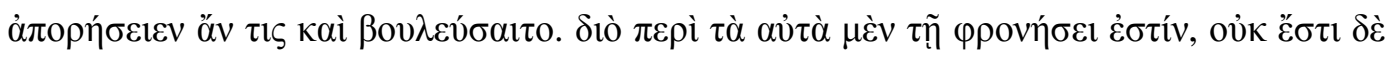

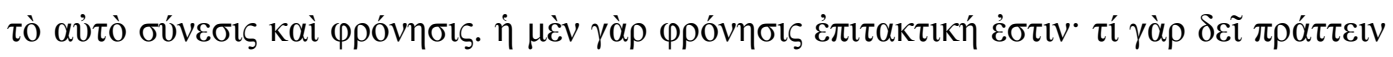

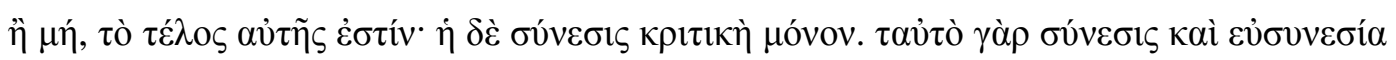

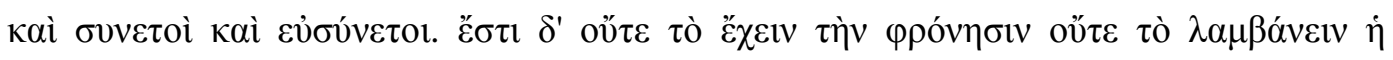

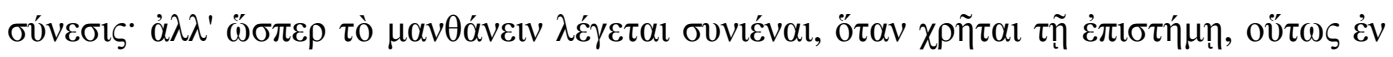

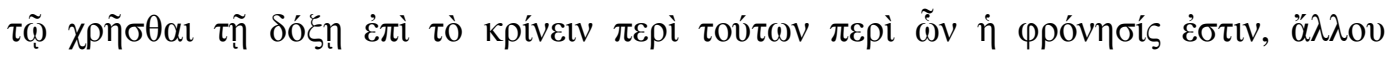

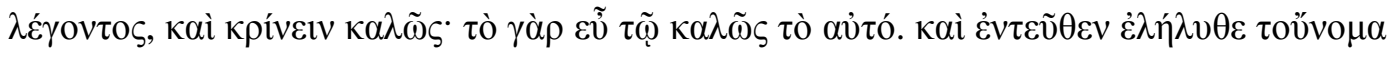

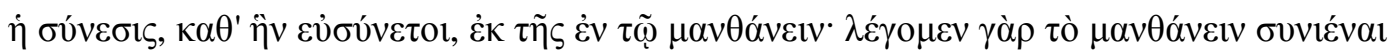
$\pi \mathrm{o} \lambda \lambda \alpha \dot{\alpha} \kappa \varsigma$.

A megértés ${ }^{11}$ és a jó felfogás, amelyek alapján némelyeket 'értelmesnek' és 'jó felfogásúnak’ mondunk, nem azonos az általában vett tudományos tudással vagy a véleménnyel (ez esetben ugyanis mindenki ‘értelmes' lenne), nem is egyike a valamely

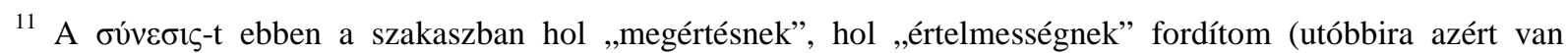

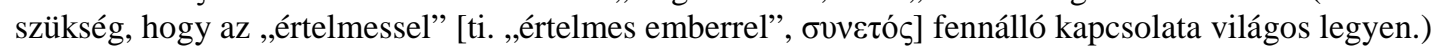


részterülettel foglalkozó tudományos tudásfajtáknak, amilyen az orvoslás, amely az egészséggel, vagy a geometria, amely a nagysággal foglalkozik. Mert a megértésnek nem tárgyai sem az örök és mozdulatlan létezők, sem pedig a keletkezők közül valamelyik, hanem azok a kérdések, amelyek felől valaki bizonytalanságban lehet, és amelyeket megfontolhat.

Ennélfogva a megértés ugyanazokra a dolgokra vonatkozik, mint a gyakorlati bölcsesség, de azért mégsem ugyanaz a kettő. A gyakorlati bölcsesség ugyanis rendelkezik: az a célja, hogy megállapítsa, mit kell vagy mit nem szabad megtennünk; a megértés azonban csak ítéletet mond: mert 'értelmesség' annyi, mint 'jó felfogás', és 'értelmes' annyi, mint 'jó felfogású' ember.

Másfelől a megértés nem jelenti a gyakorlati bölcsességnek sem a birtoklását, sem a megszerzését; hanem ahogyan a 'tanulni' szót 'megérteni' jelentésben használjuk akkor, amikor a tudományos tudást alkalmazzuk, úgy a megértés azt jelenti, hogy a véleményalkotást használjuk fel olyan kérdések megítélésére, amelyek a gyakorlati bölcsesség tárgyai, olyan esetekben, amikor valaki más beszél ezekröl - mégpedig e kérdések helyes megítélésére, mert a 'jól' és a ‘helyesen’ ugyanaz. A ‘megértés' kifejezés tehát, melynek alapján valakit 'értelmesnek’ mondunk, a tanulással kapcsolatban használt 'megérteni' kifejezésből származik, mert a tanulást sokszor 'megértésnek' mondjuk (EN VI. 11. 1142b34-1143a18).

Ezt a bonyolult szakaszt most kizárólag a kérdésföltevésem szempontjából fontos összefüggésre összpontosítva értelmezem, vagyis kizárólag a phronésis és a synesis közötti viszonyt tartva szem előtt. Mindkét intellektuális képesség ugyanazon a területen müködik, nevezetesen a cselekvés (praxis) területén. Mivel az emberi cselekvés olyasmikre irányul, amik „másképpen is lehetnek”, és mivel az efféle dolgokra nem vonatkozik demonstratív, tudományos tudás (epistémé), a phronésis és a synesis nem azonos a tudományos tudással (EN VI. 2. 1139a6-14; 3. 1139b19-24; 5. 1140a30-b7; 6. 1140b26-28; 1141a1; vö. Metaph. II. 1. 993b20-23). E két dianoétikus erény olyan dolgokra irányul, melyekkel kapcsolatban valaki bizonytalanságban lehet, és amelyek megfontolás tárgyai lehetnek. Ez egyfelől annyit jelent, hogy mind a gyakorlati bölcsességnek, mind a megértésnek vagy értelmességnek ugyanazokkal a tárgyakkal van dolga, nevezetesen a megfontolás, a buleusis tárgyaival. Másfelöl azonban e két erény között különbség van abban a tekintetben, hogy míg a gyakorlati bölcsesség a megfontolás folyamatának lezárultával elöírja a cselekvés egy

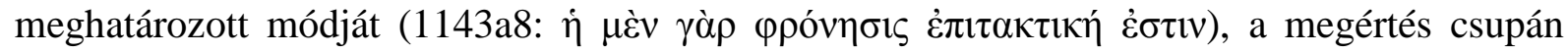
értelmezi és megítéli a cselekvési helyzetet és a helyes cselekvés lehetőségét az adott 
helyzetben, anélkül azonban, hogy a végrehajtandó cselekvés menetét pontosan elöírná (a9sk.:

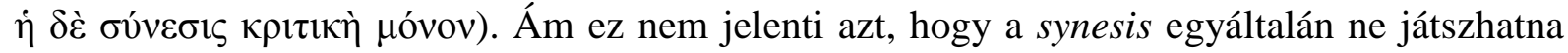
valamiféle szerepet a megfontolásban. A megértés ugyanazon a módon kutat és okoskodik, mint a gyakorlati bölcsesség, csakhogy okoskodásának végeredménye nélkülözi a cselekvésre késztető erőt: felöltheti a felszólító mód alakját, de nem követel engedelmességet. ${ }^{12} \mathrm{~A}$ megértés egyfajta felfogás, megragadás, amely egyfelől a tudományos tudás területével érintkezik, ezért kapcsolódik össze a „tanulással (manthanein)” és az epistémével (ebben az összefüggésben a synienai a tanulás „felfogó”, „megértő” mozzanatára utal). ${ }^{13}$ Másfelől viszont a megértés a gyakorlati élet összefüggésrendjében nyeri el jelentését és szerepét, ezért

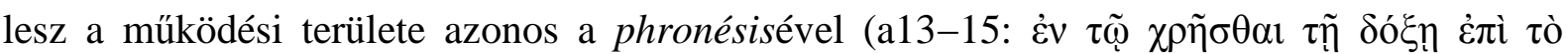

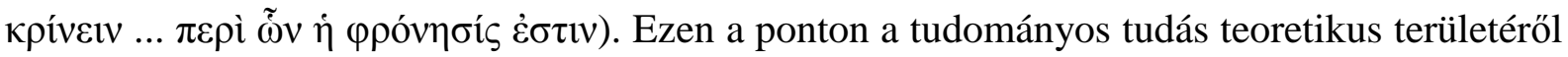
átlépünk a megfontolás és a gyakorlati bölcsesség praktikus területére, ahol erkölcsi kérdésekről alkotott vélemények között kell döntenünk.

A synesis legfontosabb feladata ezen a területen a megkülönböztetés vagy ítélet (a14,

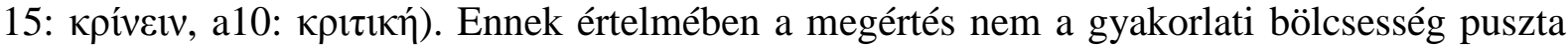
passzív birtoklásában áll, nem is a gyakorlati bölcsesség megszerzésének előfoka és így annak alacsonyabb szintű megvalósulása. A megértés a gyakorlati bölcsesség müködtetése annak rendelkezö, elöiró funkciója nélkül. Ennélfogva például olyan helyzetekben élünk vele, amelyekben nem vagyunk személyünkben közvetlenül érintve, hanem amikor másvalaki

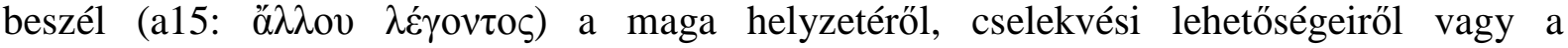
cselekvéssel kapcsolatos morális dilemmáiról, s mi ezt felfogjuk, megértjük, megítéljük, és mondjuk tanácsot adunk neki - mely tanács nélkülözi a kényszerítő erőt. Vagy ugyanígy, amikor múltbeli tetteiről ad számot valaki, s mi megértjük az elmondottakat, és esetleg bíráljuk vagy éppenséggel megdicsérjük az illetőt. Ez nem megfontolás a szó szigorúan technikai értelmében, amennyiben a megfontolás szűkebb értelemben olyasmire vonatkozik, ami rajtunk áll és amit megtehetünk (EN III. 5. 1113a9-12; hasonlóan 1112a30sk., 1112b32). Éppenséggel persze olyan helyzetekben is gyakorolhatjuk a synesist, amelyekben cselekednünk kell: ekkor azt a képességet jelentheti, amellyel felfogjuk és megítéljük azt, amit mások mondanak a mi helyzetünkröl és cselekvési lehetőségeinkröl (EN III. 5. 1112b10sk.). Hursthouse hangsúlyozza a synesisnek ezt a szerepét, vagyis amelyet annak a helyzetnek a megértésében játszik, amelyben - másoknak a mi helyzetünkről nyújtott

\footnotetext{
${ }^{12}$ Reeve: i. m. (6. jegyz.) 225.

${ }^{13}$ Vö. Metaph. XI. 5. 1062a11-13, ahol a synesis a logos megértésének nyelvi előfeltétele. „Azoknak tehát, akik

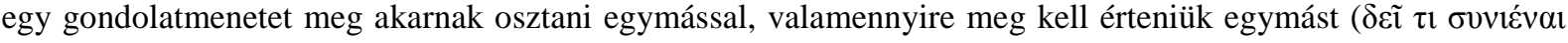

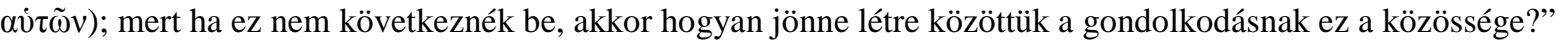


felvilágosításai és helyzetértékelése alapján - már nekünk kell cselekednünk. ${ }^{14}$ A synesisnek ez a müködése már tekinthető úgy, mint amely részét alkotja a (szó technikai értelmében vett) megfontolás folyamatának, ugyanakkor ez csak a megértés alkalmazásának egyik esete lehet, de semmiképpen sem fedi le annak egészét. ${ }^{15}$

Összefoglalva: a synesis funkciói egyfelől ugyanazok, mint a phronésiséi, a cselekvést előíró vagy arról rendelkező működés kivételével. Másfelől a synesis akkor fejti ki müködését, amikor mások erkölcsi problémáit hallgatjuk, értjük és ítéljük meg, vagy amikor a mások által a mi helyzetünkről adott felvilágosításokat és megállapításokat értékeljük. A synesis nem a gyakorlati bölcsesség egy sajátos változata, másfelöl nem is tőle független erény, hanem egy neki alárendelt minőség, ,amely nélkül a legfőbb gyakorlati erény nem lenne teljes."16 A megértésnek az a sajátos szerepe, amely teljessé teszi a gyakorlati bölcsességet, abban áll, hogy a személyest megnyitja a személyközi felé, s ezáltal módot ad a helyes cselekvés kérdéseinek fontolóra vételére a személyközi viszonylatok területén. „Amikor megnyitjuk értelmünket arra, amit másvalaki mond, s ennek során helyesen ítéljük meg azt, amit ez a másik mond, akár egy epistémé tanulása során, akár a phronésis valamely tárgyáról alkotva ítéletet - pusztán megértő módon, mondhatnánk -, akkor a synesisünket fogjuk munkára."17 A synesis a másik ember eltérő nézőpontjának, érdekének és helyzetének megértését jelenti, és ennek alapján ,a másik racionális választásának” értékelését. ${ }^{18} \mathrm{~A}$ megértés mint „gyakorlati reflexió”19 a phronésis egy nélkülözhetetlen „,aspektusát”20 testesíti meg, vagy még inkább: a phronésis egy dimenzióját, nevezetesen ennek működését a személyközi, majd innen a társas, és végül a politikai viszonyok közegében. ${ }^{21}$

\footnotetext{
${ }^{14}$ R. Hursthouse: Practical Wisdom: a Mundane Account. PAS 106 (2006) 291sk.

${ }^{15}$ Contra R. Hursthouse: i. m. (14. jegyz.). Vö. Ebertnek a synesisröl adott magyarázatát, mely szerint ez a mások által adott tanácsnak és mások magatartásának a megítélésére szolgáló képesség, vagyis olyan tárgyakra vonatkozik, amelyek nem esnek a mindenkori saját megfontolás körébe. (Th. Ebert: Phronēsis. Anmerkungen zu einem Begriff der aristotelischen Ethik (VI 5, 8-13). In: Aristoteles: Die Nikomachische Ethik. Hg. von $O$. Höffe. Berlin 1995. 174.) Más szempontból persze Hursthouse példája szépen megmutatja az individuális és a közösségi vagy az etika és a politika közötti határok átjárhatóságát Aristotelés gyakorlati filozófiájában. A tanulmányom harmadik részében elemzett második példában (Pol. IV. 4. 1291a28) a synesisnek kifejezetten a (politikai) deliberáció a feladata vagy funkciója (ergon).

${ }^{16}$ W. F. R. Hardie: Aristotle's Ethical Theory. Oxford 1968. 221.

${ }^{17}$ O. Eikeland: Phrónēsis, Aristotle, and action research. International Journal of Action Research 2 (2006) 24.

${ }^{18}$ S. Broadie: Ethics with Aristotle. Oxford 1991. 253.

${ }^{19}$ H. Segvic: Deliberation and Choice in Aristotle. In: Moral Psychology and Human Action in Aristotle. Edd. M. Pakaluk-G. Pearson. Oxford 2011. 175.

${ }^{20}$ C. D. C. Reeve: i. m. (6. jegyz.) 3.

${ }^{21}$ Vö. H. Segvic: i. m. (19. jegyz.) 174-176, hangsúlyozva a synesisben rejlő közösségi elemet, de politikai szerepének említése nélkül. $R$. Bodéüs: i. m. (10. jegyz.) 103-105 szerint a megértés legfőbb feladata a gyakorlati (tehát erkölcsi-politikai) kérdésekről folytatott diskurzus kritikai megítélése, valamint hogy képessé tegyen bennünket arra, hogy megítéljük azokat a szabályokat (törvényeket), melyeket a törvényhozó ad a polisnak. Aristotelés felfogásában e két elem mindenféle politikai tevékenység előfeltételét jelenti. ( $E N$ X. 10 . 1180 b23skk.) Ebben az összefügésben az is említést érdemel, hogy az EN első könyvének végén, ahol a synesis
} 
Aristotelés a következő szakaszban folytatja a phronésis személyközi vetületeinek tárgyalását, a gyakorlati intellektuális erények sorába a synesis mellé fölvéve a gnómét („megértő gondolkodás”) és a syngnómét (,elnéző” vagy akár „megbocsátó gondolkodás”) is. A synesis olyan szorosan kapcsolódik az utóbbi két fogalomhoz, hogy jelentésük részben fedi egymást. $^{22} \mathrm{E}$ fogalmak Aristotelés számára nagyjából-egészében ugyanarra a képességre vonatkoznak, s a szakasz végére világossá válik, hogy a szóban forgó erények a közösségben élő emberi lény legfontosabb intellektuális erényei:

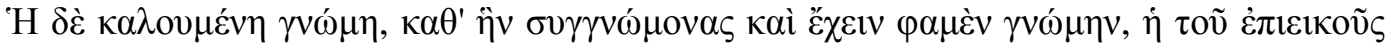

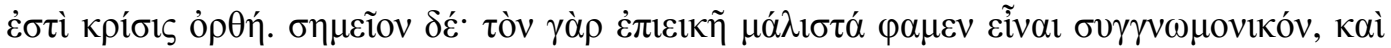

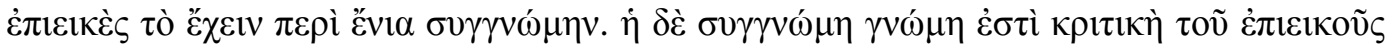

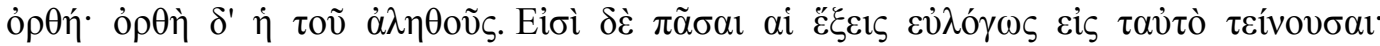

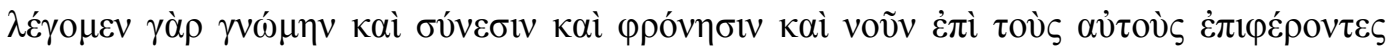

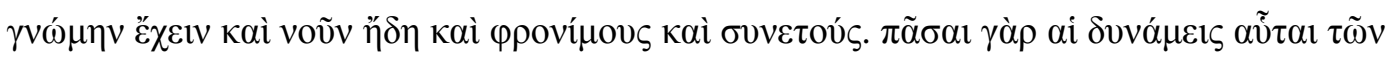

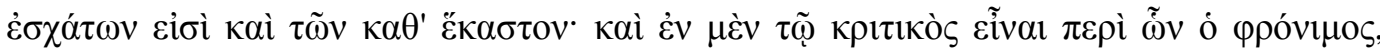

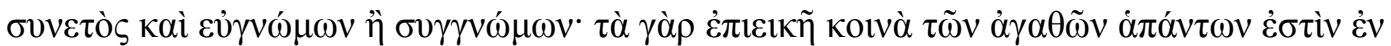
$\tau \tilde{\oplus} \pi \rho \grave{\varsigma} \varsigma \ddot{\alpha} \lambda \lambda \sigma o v$.

Az úgynevezett 'megértő gondolkodás', amelynek alapján némelyekről azt mondjuk, hogy 'jóindulatúan gondolkodnak' és hogy van bennük megértés, annak helyes megítélését jelenti, hogy mi méltányos. Ennek jele az, hogy elsősorban a méltányos embert tartjuk elnézőnek, méltányosságnak pedig azt, ha valaki bizonyos kérdésekben elnéző megértéssel nyilvánul meg. Az elnéző megértés viszont az a megértő gondolkodás, amely a méltányosság tekintetében helyesen ítél. A helyes ítélet pedig az, amelyik az igazat ragadja meg. Valamennyi említett beállítódás, érthető módon, ugyanarra irányul, hiszen amikor megértő gondolkodásról, megértésről, gyakorlati bölcsességről vagy észről beszélünk, ezeket ugyanazokra vonatkoztatjuk, tehát ugyanazokról mondjuk, hogy van bennük megértés, van eszük, megvan bennük a gyakorlati bölcsesség és értelmesek. Ezek a képességek ugyanis mind a végpontra, vagyis az egyes esetekre vonatkoznak, és ha valaki olyan kérdésekben, melyekben a bölcs ember megmutatkozik, ítéletet tud mondani,

először fordul elő e müben, éppen ez a fogalom szolgál példaként az értelmi erények közül, a phronésis és a sophia társaságában (1103a4-6), s nem például az epistémé, a techné vagy a nus, melyek amúgy a dianoétikai aretai kanonizált formái az $E N$ VI-ban.

${ }^{22}$ A szakasz gondolatmenetéhez (vitatható szövegjavítási javaslattal) lásd T. Engberg-Pedersen: Converging Aristotelian Faculties: A Note on Eth. Nic. VI xi 2-3 1143a25-35. JHS 99 (1979) 158-160; a tárgyalt fogalmak közötti összefüggéshez: T. Engberg-Pedersen: Aristotle's Theory of Moral Insight. Oxford 1983. 213, valamint C. D. C. Reeve: i. m. (6. jegyz.) 230. 
az egyúttal már értelmes, jóindulatú és elnéző is; mert a méltányosság valamennyi jó embernek közös vonása a másokkal való viszonyban (EN VI. 11-12. 1143a19-32).

Ebből a szakaszból világossá válik, hogy ezek a képességek nemcsak intellektuális vagy racionális szellemi aktivitást jelentenek, hanem egyfajta megértő vagy elnéző attitüdöt is megtestesítenek. Mindazonáltal érdemes hangsúlyozni azt is, hogy esetükben a lényeg nem is egyszerűen az „együttérzés” altruisztikus erénye, vagy a „megértés” a puszta elviselés, elnézés vagy megbocsátás értelmében. Ebben az összefüggésben a gnómé és a syngnómé egyszerre hordoz a kognícióra és az interperszonális megértésre utaló jelentéstartalmakat, ${ }^{23} \mathrm{~s}$ ezek a tartalmak még sajátosabban annak megítélésében összpontosulnak, hogy egy adott

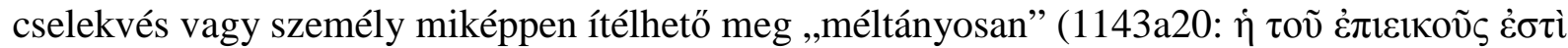

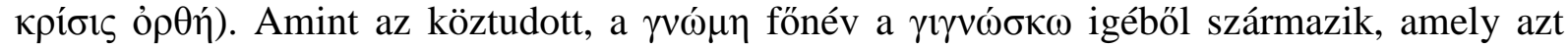
jelenti, hogy „érzékel”, „tud”, „megismer” valamit, s így a gnómé jelentései közül azok a meghatározóak, amelyek a „megismerés” jelentésmezőjén helyezkednek el (,ítélet”, „gondolat”, „értelem” stb.). Gyakorlati kontextusban a gnómé azt a „gondolatot, véleményt vagy gyakorlati maximát” jelenti, ,amely ezt az ismeretet kifejezi vagy megtestesíti”. ${ }^{24}$ Szükebb értelemben, ahogyan a föntebb idézett szövegrészben is, a gnómé a méltányosságra utal (Rh. II. 15. 1375a27-31). Másfelől viszont a szó vonatkozhat diszpozíciókra, hajlamokra vagy akár érzelmekre is (pl. Pi. O. 3. 41; Hdt. VI. 37, IX. 4; Th. VI. 45). Vagyis a gnómé jelentéstartománya egyszerre foglal magában kognitív és affektív területeket. ${ }^{25}$ Franz Dirlmeiert követve pedig úgy fogalmazhatunk, hogy a syngnómé „elnéző gondolkodás”, „elnézés” értelemben való használata a fenti szakaszban arra utal, hogy azzal szemben vagyunk elnézőek, vagy akár annak tudunk megbocsátani, akinek a megfontolásait meg tudjuk érteni, akivel képesek vagyunk „együtt gondolkodni” (syn-gnómé, syn-gignóskó). ${ }^{26}$

Anélkül, hogy a szakasz másik kulcsfogalmának, a méltányosságnak (epieikeia) a tárgyalásába részletesen belebocsátkoznék, csupán arra hívom föl a figyelmet, hogy amikor itt Aristotelés a méltányosságot említi, akkor voltaképpen arra az erényre utal, amely az igazságosság (dikaiosyné) kiegészítő vagy egyenesen kiigazító erénye (EN V. 14. 1137b813). Ennek megfelelően az epieikeia - csakúgy, mint a dikaiosyné - nem érthető meg pusztán valaki individuális jellemének az alapján, hanem sajátlagos értelmét már meghatározása

\footnotetext{
${ }^{23}$ P. Aubenque: Begriff der Klugheit bei Aristoteles. Hamburg 2007. 145sk.; H. Segvic: i. m. (19. jegyz.) 175sk.

${ }^{24}$ C. D. C. Reeve: i. m. (6. jegyz.) 228; vö. Rh. II. 21. 1394a21-25.

${ }^{25}$ C. D. C. Reeve: i. m. (6. jegyz.) 229sk.

${ }^{26}$ Aristoteles: Nikomachische Ethik. Übersetzt von F. Dirlmeier. Berlin 1956. 465; Gadamer (Aristoteles: Nikomachische Ethik VI. Herausgegeben, übersetzt und kommentiert von $H$-G. Gadamer. Frankfurt am Main 1998. 14) a synesis értelmező fordítására a „Verständnis und Verstehen” megfogalmazást használja.
} 
szerint is valamilyen személyközi viszonyban nyeri el, mert - csakúgy, mint az igazságosság

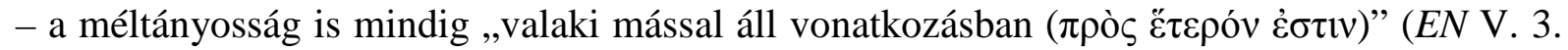
1130a3sk.). ${ }^{27}$ Ahogyan a gnóméról és syngnóméról szóló szakasz végén láttuk, „a méltányosság valamennyi jó embernek közös vonása a másokkal való viszonyban

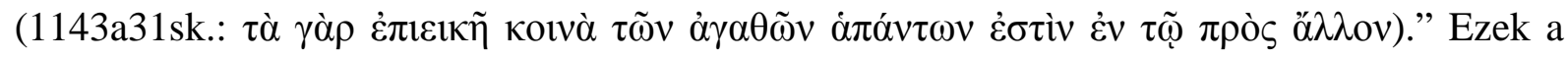

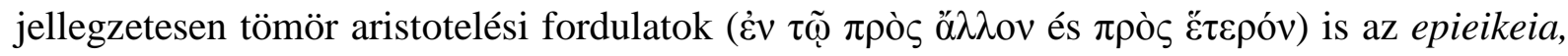
gnómé és syngnómé személyközi, közösségi és politikai jellegét mutatják, mivel e frázisok Aristotelésnél mindig személyközi viszonyokra utalnak, ennek révén pedig az emberi élet közösségi vagy politikai alapjára. Továbbá mivel a syngnómé olyasvalami, ami szükségképpen másokkal köt össze bennünket, „ez akkor nyilvánul meg, amikor a jóról, az igazságosságról és egyéb gyakorlati értékekről cserélünk eszmét, ennek következtében pedig ezeknek az értékeknek és annak megértése, hogy ezek mit jelentenek az egyedi körülmények között, maga is valami megosztottá, közössé és közösségivé válik."28 Az itt tárgyalt fogalmak dialogikus jellege lényegi eleme jogi és politikai relevanciájuknak. A synesis esetében pedig ennél is többröl van szó: a dialogikus karakter itt elöfeltétele emez erény jogi és politikai alkalmazásának.

\section{II}

A dolgozatom első részének elején idézett szakasz végén Aristotelés a következőt mondja: „A 'megértés' kifejezés tehát, melynek alapján valakit 'értelmesnek' mondunk, a tanulással kapcsolatban használt 'megérteni' kifejezésből származik, mert a tanulást sokszor

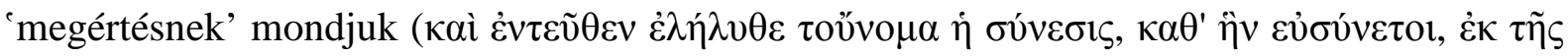

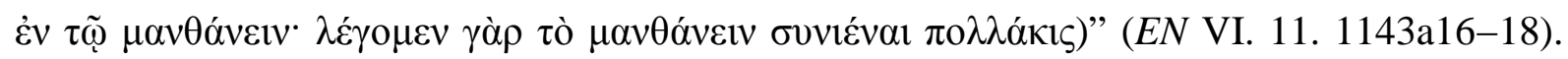
Ennek a magyarázatnak vannak párhuzamai Aristotelés más müveiben (Top. VII. 6. 160a18-22; SE 4. 165b32-34) és Platónnál is (Euthd. 278a4sk.). E magyarázat gyökere pedig, ahogyan maga Aristotelés is jelzi ezt a most idézetteket megelőző sorokban (1143a12-15), a tanulás teoretikus összefüggéseibe nyúlik le, ahol „tanulásról/megértésrooll” (manthanein) „kétféle értelemben beszélünk: egyrészt arra utalva vele, amikor a tanuló elöször tanul meg (sajátít el) valamit, másrészt arra, amikor valaki már uralja tárgyát és gyakorolja a tárgyára

\footnotetext{
${ }^{27}$ Vö. EN V. 3. 1129b25-27, 1129b31-33; 9. 1133b32-1134a1, és az epieikeia tárgyalását az 1137a31skk.-ban.

${ }^{28}$ C. D. C. Reeve: i. m. (6. jegyz.) 229.
} 
vonatkozó tudását. Ezért hangsúlyozza Aristotelés, hogy az erkölcsi megértés a jó ítélőképességnek nem a megszerzése, hanem a gyakorlása." 29

Ily módon a synesis jelentése ebben a szövegösszefüggésben a teoretikus tudás területétől a praktikus tudás területe felé mozog, de ez az átvitel vagy alkalmazás egyáltalán nem önkényes vagy „erőszakos”. ${ }^{30}$ Dolgozatom második részében néhány példa segítségével azt próbálom megmutatni, hogy a synesis szemantikai térfogata, Homérostól Thukydidésig, tartalmazta a szociális vagy akár a politikai jelentésmozzanatát, jóllehet ez a mozzanat egyáltalán nem volt kizárólagos, sőt talán még csak központi sem. Ugyanakkor ez a mozzanat Platónnál, Thukydidésnél és magánál Aristotelésnél is több olyan összefüggésben is látványosan megmutatkozik, amely fontos témánk szempontjából.

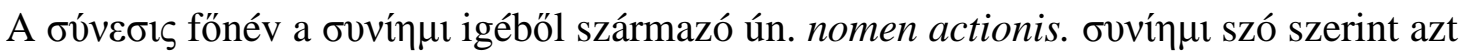
jelenti, hogy „együtt/együvé küld,” „összehoz” vagy „(ellenségként) szembeállít”. Innen azután, szellemi müveletre utalva, azt az elmebeli képességet jelenti, hogy dolgokat aktívan összehozunk, egymás mellé állítunk oly módon, hogy ezek egyetlen értelmi egységgé álljanak össze, melyet valaki ilyenként megragad vagy megismer. ${ }^{31}$ Továbbá aktív igeként azt is jelenti, hogy valaki „érzékel”, „hall”, „megért” valamit, mediális alakja pedig „összejön” „egyezségre jut” értelemben használatos (utóbbi jelentése sok szempontból hasonlít a latin convenio ige jelentésbokrának némely ágaihoz). Az ige jelentéséhez ily módon eleve hozzátartozik ,,a közösségi vagy dialogikus dimenzió”. 32 A főnév „egyesülést”, „egységet” is jelent, valamint „megértést” és „gyors felfogóképességet”. Mindent egybevéve: a synesis és a vele rokon szóalakok csoportja világosan jelzi, hogy a szó jelentésmagva „olyanfajta intelligenciát jelöl, amely mások felé irányul és amely másokkal való bensőséges kapcsolatra vonatkozik." 33

Bruno Snell részletekbe menően vizsgálta a synesis szó és fogalom történetét. ${ }^{34}$ Vizsgálódásainak eredménye világossá teszi, hogy a szó Homérosznál nem egyszerủen azt jelenti, hogy „hallgatni (valakire)” (anhören) vagy „megérteni (valakit)” (verstehen), hanem közel van a „követni (valakit)” (folgen), „engedelmeskedni (valakinek)” (gehorchen)

\footnotetext{
${ }^{29}$ S. Broadie: Commentary. In: Aristotle: Nicomachean Ethics. Translation (with Historical Introduction) by $C$. Rowe, Philosophical Introduction and Commentary by S. Broadie. Oxford 2002. 377.

${ }^{30} H$-G. Gadamer: i. m. (26. jegyz.) 14 jegyzi meg erről az alkalmazásról, hogy az „nicht ohne leichte begriffliche Gewaltsamkeit" történik. Vele szemben P. Aubenque: i. m. (23. jegyz.) 114 és 146 helyesen hangsúlyozza, hogy Aristotelés ekkor éppenséggel visszaadja a szónak az archaikus jelentését, melyet éppen hogy a gyakorlatitól térítettek el az elméleti irány felé.

${ }^{31}$ C. D. C. Reeve: i. m. (6. jegyz.) 224.

${ }^{32}$ C. P. Long: The ontological reappropriation of phronēsis. Continental Philosophy Review 35 (2002) 58; O. Eikeland: i. m. (17. jegyz.) 23sk.

${ }^{33}$ C. P. Long: i. m. (32. jegyz.) 58.

${ }^{34}$ B. Snell: Die Ausdrücke für den Begriff des Wissens in der vorplatonischen Philosophie. Berlin 1924. 40-59.
} 
jelentéshez (pl. Il. I. 273; II. 26, 182; XV. 442; Od. I. 271; VI. 289). A ouvtéval szót nem használják abban az esetben, ha a megnyilatkozás hallgatójának cselekvése eltér a beszélő által szándékolttól (vagy legalábbis javasolttól). ${ }^{35}$ A presókratikus filozófiában a ovvićvaı nem annyira a világ érzékelését vagy megismerését jelenti, hanem a világnak mint értelmes, ésszerüen elrendezett egésznek, egyszersmind pedig mint olyan valaminek a megértését, ami megszólítja és tanítja a bölcset (Heraclit. fr. 51; Alcmaeon fr. 1a; Meliss. fr. 8, Democr. fr. 9.

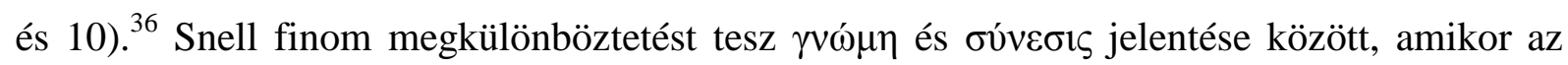
előbbit az érzékelhető dolgok objektív ismereteként határozza meg, az utóbbit viszont olyan tudásként, amelynek alapja a belehelyezkedés a megértendőbe, vagyis a megértés. ${ }^{37}$

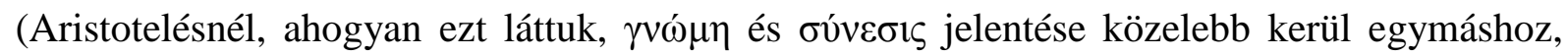
mégpedig oly módon, hogy mindkét szó jelentésének meghatározó közös mozzanata az empatikus és érzékeny megértés lesz.) A szofistáknál veszi fel a synesis az „ész” (Vernunft) jelentést; Euripidésnél egyaránt vonatkozhat isteni és emberi észre is (HF 655sk.; Hipp. 1105; Suppl. 203; Tr. 671sk.; IA 375; Or. 396 [itt a szó jelentése 'tudatában lenni valaminek', ahogyan a lelkiismeret tudatában van az elkövetett bủnnek], 1524). ${ }^{38}$ Aristophanés pontosan a szó ilyen értelmű használatáért gúnyolja ki Euripidést a Békákban (893, 1483). Az attikai szónokok inkább kerülik a szót, vagy ironikusan használják azt (vö. Dem. De cor. 127. 6), vélhetőleg jelentésének - a szofista használat által meghatározott - szubjektivisztikus és nihilista árnyalata és modorosnak érzett ,intellektualizmusa” miatt. ${ }^{39}$

Ugyanakkor ismerünk két olyan athéni szerzőt, Platónt és Thukydidést, akiknek

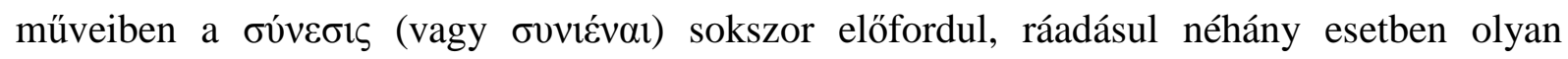
jelentésben, amely közel van ahhoz, ahogyan Aristotelés használja a szót. ${ }^{40}$ Platón Államában (376b) azt olvassuk, hogy ha a kutyák megpillantanak valakit, azt attól függően kezelik barátként vagy ellenségként (philosként vagy echthrosként), hogy az illető látványa ismerős-e nekik vagy sem. Ennek során pedig az ismerős és az idegen (oikeion és allotrion) között a

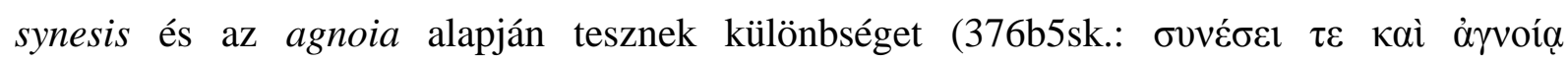

\footnotetext{
${ }^{35}$ B. Snell: i. m. (34. jegyz.) 40. Ez a jelentés összevethető a ovvićval előfordulásával az EN X. 10. 1179b27-ben és X. 1. 1172b6-ban, ahol 'megérteni' közel van az 'engedelmeskedni' vagy a 'hallgatni az észre' jelentéshez $(R$. Bodéüs: i. m. [10. 1j.] 99).

${ }^{36}$ B. Snell: i. m. (34. jegyz.) 48sk.

${ }^{37}$ B. Snell: i. m. (34. jegyz.) 55.

${ }^{38}$ B. Snell: i. m. (34. jegyz.) 56.

${ }^{39}$ B. Snell: i. m. (34. jegyz.) $57 \mathrm{sk}$.

40 Mindazonáltal a synesis Platónnál gyakran fordul elő olyan szavak szinonimájaként vagy legalábbis jelentésbeli rokonaként is, amelyek a teoretikus tudásra vonatkoznak, pl. Phil. 19d4sk. (nusszal, epistémével és technével együtt); Crat. 411a7sk. (phronésis, gnómé és epistémé társaságában) 437b6 (epistémével); Soph. 228c10-d2 (szembeállítva agnoeinnel); a phronésisröl Platónnál lásd M. Lenzi: Plato's Equivocal Wisdom. Newsletters for the Society for Ancient Greek Philosophy 5 (2004) 1-11.
} 


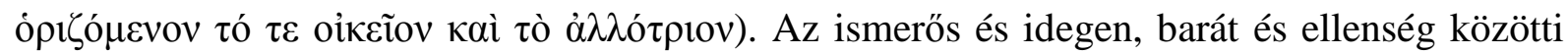
különbségtevés képességeként a synesis jelentéstartalmában már itt is megnyilvánul a gyakorlati, közösségi vagy politikai mozzanata. Ez a jelentésmozzanat még határozottabban mutatkozik meg az Államférfi című dialógus egy helyén (259c-d), ahol arról van szó, hogy az emberi közösségek vezetése (arché), függetlenül ezek nagyságától, egyetlen tudománynak, az epistémé basilikének a tárgya (melyet politikének vagy oikonomikének is neveznek). Ami pedig a vezető segítségére van abban, hogy megtartsa hatalmát (arché), az nem a testi erő,

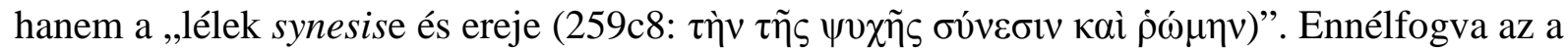
tudás, amellyel az állam vezetőjének rendelkeznie kell, egyszerre megismerő jellegü

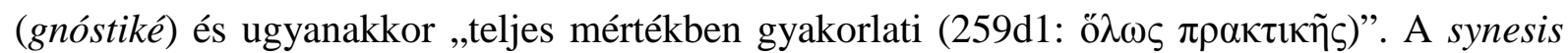
tehát ezen a helyen a közösség vezetőjének politikai tudását és képességét jelöli, s kifejezetten a praxishoz kapcsolódik.

Thukydidésnél Themistoklés „természetes” vagy „veleszületett” (szó szerint

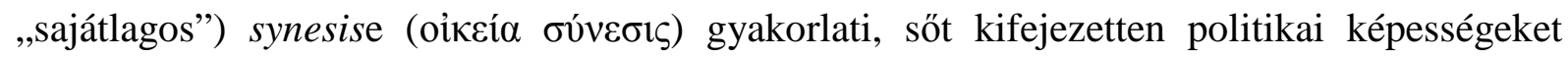
foglal magában: pontos helyzetfelismerést, helyes gyakorlati ítéletet (gnómé) és a szónoki meggyőzés erényét (peithein) (I. 138. 3; lásd még I. 14. 3; I. 90. 3; I. 91. 1; I. 93.3 és 5). (Egyébként már Hérodotos is hasonló vonásokkal ruházta fel Themistoklést, azzal a különbséggel, hogy ö a synesis és a synetos helyett a sophiát és a sophost használja; ehhez azonban tudnunk kell, hogy Hérodotosnál a sophia elsősorban gyakorlati intelligenciát, a politikai ügyekben megmutatkozó okosságot jelenti [pl. VIII. 110, ahol a sophos kétszer is előfordul, az eubulia és a peithein társaságában; VIII. 124.]) A synesis ilyen értelmü használata kerül át azután - némi jelentésmódosulással, amelynek forrása éppenséggel valószínüleg Aristotelés synesis-értelmezése volt - Thukydidéstől Plutarchos Themistoklésjellemzésébe (Them. 2). ${ }^{41}$

Az eddig elmondottak alapján aligha meglepő, hogy Aristotelés gyakorlati filozófiájában a synesis fogalma, amely a „megértésre” utal mint a praktikus intelligencia egy formájára, amely dialogikus és személyközi vagy társadalmi viszonyt foglal magában, politikai jelentőségre tesz szert. Annak a két szövegrésznek az értelmezése előtt azonban, ahol a synesis kifejezetten politikai kontextusban bukkan föl, vizsgáljuk meg röviden a szó egy olyan előfordulását, amely valószínűleg a legközelebb áll ahhoz a jelentéshez, amelyben Platón használja a szót az imént röviden megidézett szövegeiben. Itt első sorban az oikeion és allotrion közötti megkülönböztetésre kell gondolnunk, s ezzel összefüggésben az oikosra mint

\footnotetext{
${ }^{41}$ H. Martin Jr.: The Character of Plutarch's Themistocles. TAPhA 92 (1961) 326-339, további helyekkel. Martin a synesis fordításaként a ,practical intelligence” kifejezést javasolja Plut. Them. 2. kontextusában.
} 
„családra”, valamint az oikonomia vagy oikonomiké fogalmára, amely a társas és politikai (értsd: polis-alkotó) viszonyok ezen elemi formájával kapcsolatos tudásra vagy szakismeretre utal, s amely Aristotelés szerint ugyancsak a személyes ügyek intézésén túlmutató phronésist igényel (EN VI. 8-9. 1141b29-1142a11).

A családtagok közötti „barátság” (syngeniké philia) különböző formáit taglalva Aristotelés a Nikomachosi etika nyolcadik könyvében különbséget tesz a szülök gyermekeik iránti, s a gyermekek szüleik iránti philiája között (VIII. 14. 1161b16-30). Ez az érzelmi viszony számos okból nem tekinthető tökéletesen szimmetrikusnak. Az egyik oka ennek az, hogy „a szülők mindjárt születésüktől kezdve szeretik gyermekeiket, azok viszont csak bizonyos idő elteltével kezdik szeretni szüleiket, amikor már megértésre és érzékelésre

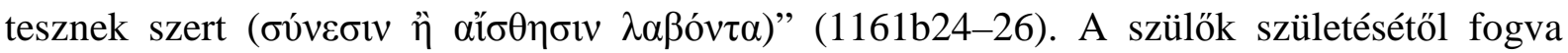
ismerik saját gyermeküket, és szeretik őt mint olyasvalakit, aki „,belőlük származik” vagy ,az

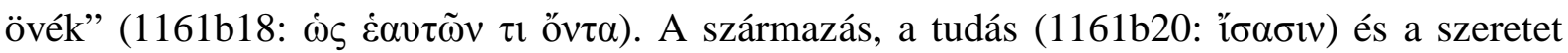
közötti kapcsolat a gyermekek oldalán viszont úgy jelenik meg, hogy ők csak bizonyos idő elteltével éreznek szeretetet szüleik iránt, amikor már fölismerik öket. Az a szó, amelyet Aristotelés használ az ebben a viszonyban bekövetkező „felismerésre”, „felfogásra” vagy „megértésre”, a synesis. Megállapítható, hogy a synesis itt nem egyszerüen „ismeretet”, s nem valamiféle semleges „felismerést” vagy „megismerést” jelent, hanem sokkal inkább egyfajta megértésre vonatkozik, mégpedig a gyermek-szülő viszony „megértésére”, s ebben a megértésben kognitív, morális és affektív mozzanatok együtt lépnek föl. Ugyanígy az aisthésisnek is többet kell itt jelentenie a sajátlagos vagy a járulékos érzékelésnél (az utóbbira lásd DA II. 6. 418a20-24). Hiszen a gyermekeknek már van érzékelésük, járulékos érzékelésük is, azelőtt is, hogy fölismernék szüleiket mint szülőket, pontosabban mint a saját szüleiket, vagy legalábbis mint olyanokat, akik hozzájuk tartoznak (oikeioi), mint olyan embereket, akik szeretettel és gondoskodással fordulnak feléjük, s akik felé, ennek a „fölismerésnek” vagy tehát „,megértésnek” az eredményeképpen, ők maguk is bizalommal és szeretettel fordulhatnak. ${ }^{42}$ A synesis tehát itt a társas kapcsolatok legelemibb formájának felfogását, megértését jelenti, a szociális képességek első megnyilvánulásátát, amely nélkül nem fejlődik ki a gyermekekben a szeretet (stergein) és a „barátság” (philia) szüleik iránt.

\footnotetext{
${ }^{42}$ J. Whiting: The Nicomachean Account of Philia. In: R. Kraut (ed.): i. m. (8. jegyz.) 289.
} 
Az első olyan hely, ahol a synesis kifejezetten politikai összefüggésben fordul elő, a Nikomachosi etika utolsó fejezete:

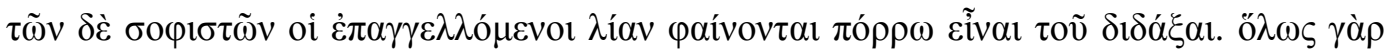

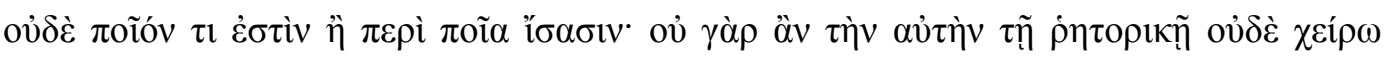

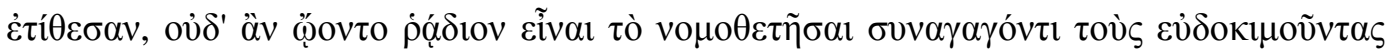

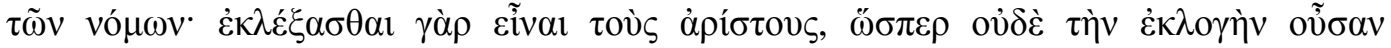

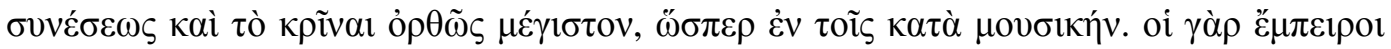

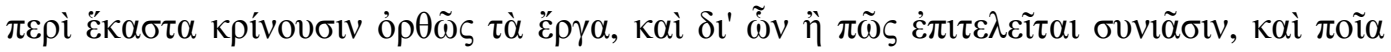

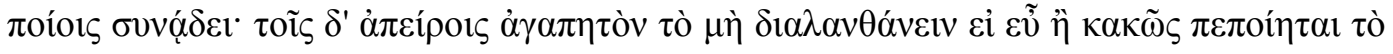

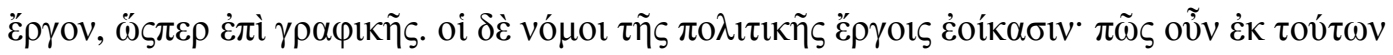

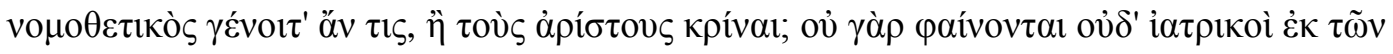

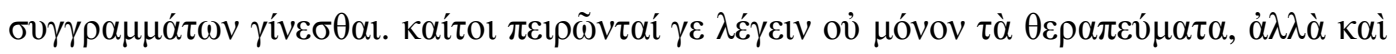

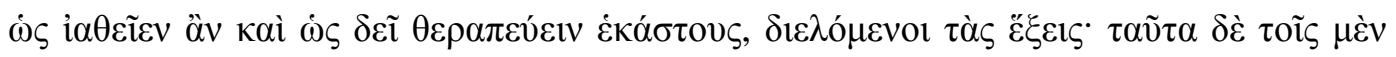

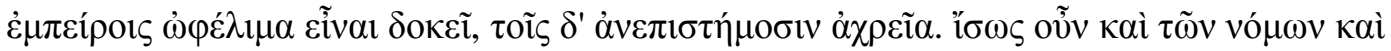

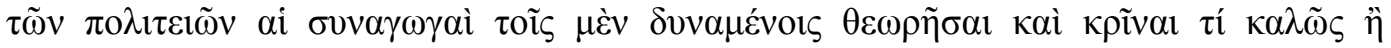

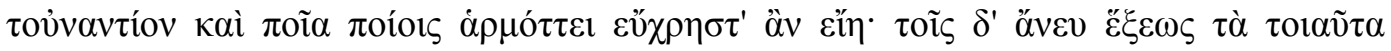

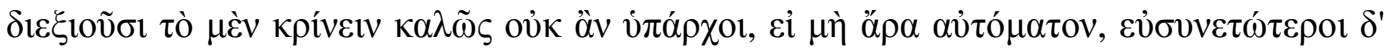

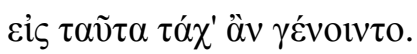

A szofisták közül azonban azok, akik ezt hirdetik magukról, nyilvánvalóan igencsak távol állnak attól, hogy a politikai tudást tanítsák. Mert általában véve mit sem tudnak arról, hogy ez milyen jellegű és hogy milyen jellegü dolgokkal foglalkozik, hiszen akkor nem helyeznék egy szintre a szónoki mesterséggel, sőt még lejjebb is annál, és nem gondolnák azt, hogy a törvényhozás könnyü, ha az ember először összegyüjti azokat a törvényeket, amelyeket jónak tartanak, s azután már ki lehet válogatni közülük a legjobbakat. Mintha a kiválogatás nem a megértés feladata lenne, és nem a helyes ítélet lenne a legfontosabb, éppen úgy, ahogyan a zene területén. Mert az egyes esetekben a tapasztaltak ítélik meg helyesen a tényeket, és ők értenek ahhoz, hogy mi által és hogyan érhető el a végeredmény, és hogy mi mivel van összhangban. A tapasztalatlanoknak viszont meg kell elégedniük azzal, ha észreveszik, hogy valamilyen mü jól vagy rosszul van elkészítve, mondjuk a festészet esetében. A törvények pedig mintegy a politikai tudás müvei. Hogyan válhatna akkor valaki e mủvek alapján törvényhozóvá, vagy hogyan tudná megítélni, hogy mely törvények a legjobbak? Hiszen nyilvánvaló, hogy orvossá sem tankönyvekből lesz valaki, még akkor sem, ha ezek a könyvek nemcsak a kezelési 
módokat kísérlik meg kifejteni, hanem azt is, hogy a különböző betegek hogyan gyógyulhatnak meg, és hogyan kell öket kezelni, mégpedig úgy, hogy ennek során megkülönböztetik a különböző testi állapotokat. Ezek a fejtegetések azoknak hasznosak, akiknek van tapasztalatuk, de akik tudatlanok, azoknak haszontalanok. Tehát a törvények és a kormányzati formák gyüjteményei is jó szolgálatot tehetnek azoknak, akik képesek alaposan megvizsgálni és megítélni, hogy melyik az, amelyik jó és szép, és melyik ennek az ellenkezője, és hogy milyen jellegü milyen jellegüvel illik össze. Akik azonban e beállítódás nélkül veszik öket sorra, azok nem fogják tudni helyesen megítélni öket, legfeljebb véletlenszerüen; bár esetleg jobban fognak érteni ezekhez a kérdésekhez (EN X. 10. 1181a12-1181b12).

Ebben a szakaszban Aristotelés a szofisták bírálatából kiindulva amellett érvel, hogy a törvények puszta összegyüjtése és a róluk szerzett csupán elméleti ismeret senkit nem tesz jó törvényhozóvá. Ehhez ugyanis megértésre, ítélőképességre és az alkalmazás képességére van szükség. ${ }^{43}$ A törvényeknek - amelyek ,mintegy a politikai tudás müvei (1181a23: $\tau \tilde{\eta} \varsigma$

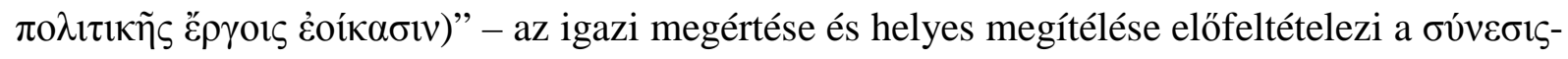
t (a18; a20sk.: бovićval) és a кpíveıv-t (a18). A számunkra legfontosabb érv a következőképpen hangzik: ha a szofisták rendelkeznének bármiféle tudással a politikéröl, akkor „,nem gondolnák azt, hogy a törvényhozás könnyü, ha az ember elöször összegyüjti azokat a törvényeket, amelyeket jónak tartanak, s azután már ki lehet válogatni közülük a legjobbakat. Mintha a kiválogatás nem a megértés feladata lenne, és nem a helyes ítélet lenne

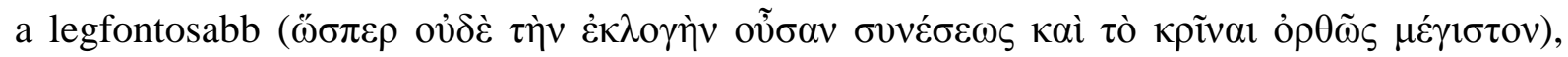
éppen úgy, ahogyan a zene területén" (1181a15-19). Első pillantásra úgy tủnhet föl, hogy a synesis itt csak valamiféle általános értelemben vett megértésben vagy megismerésben játszik szerepet, amelyet talán a kiválogatáshoz szükséges összehasonlítás képességével lehetne azonosítani (ezt a jelentést a syn-prefixum is erősítheti).

Én ezzel szemben azt állítom, egyrészt az idézett mondat tágabb szövegösszefüggése, másrészt a dolgozatom második részében tárgyalt helyek alapján, végül pedig megelőlegezve az utolsóként tárgyalandó Politika-hely (1291a24-28) elemzésének tanulságait, hogy a

\footnotetext{
${ }^{43}$ A szofisták bírálatához lásd $P$. A. Vander Waerdt: The Plan and Intention of Aristotle's Ethical and Political Writings. ICS 16 (1991) 238 észrevételét: „Their chief mistake is that they fail to recognize the difference between 'common' topics, which furnish syllogisms and enthymemes for all sciences, whatever their difference in species, and 'specific' topics, which are derived from propositions peculiar to each species or genus and which correspondingly furnish enthymemes applicable only to a particular science (...). The sophists' failure to understand this difference leads them to transgress the limits of rhetoric (...) and to lose sight of the fact that only politike can supply the 'specific' topics necessary for deliberation about practical matters."
} 
synesis használata ezen a helyen nem véletlen, s hogy nem lehetne mondjuk a gnósisszal vagy hasonló jelentésủ szóval helyettesíteni. Érveim a következők.

Először is Aristotelés a politikai tapasztalatot és a politikai tudást, valamint a belőlük származó hozzáértést vagy beállítódást az itt szerepet játszó megértés és ítélet szükséges

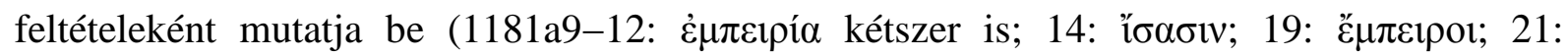

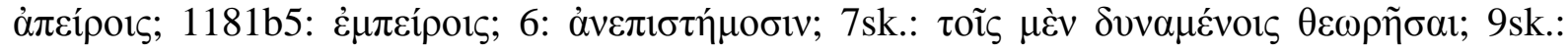

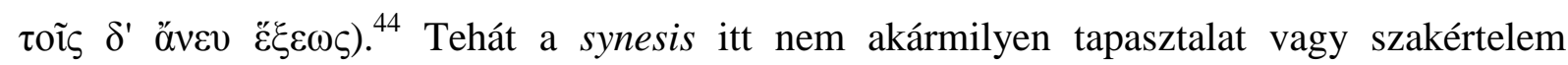
függvénye lesz, és nem akármilyen megértésre utal, hanem kifejezetten a politikai és a törvényhozói tapasztalatra és a törvények megértésére. ${ }^{45}$ És mivel a törvények ezen a helyen a politika lényegi teljesítményeként kerülnek elő, a synesis itt csakis a politikában igénybe vett szellemi erényre vonatkozhat. ${ }^{46}$

Másodszor ez az értelmezés, tehát hogy itt nem általánosságban van szó megértésről, amelyet bármilyen tárgyra alkalmazhatnánk, megtámogatható ennek a specifikus megértésnek még egy sajátosságával: azzal, hogy a törvények helyes megítélésének egy sajátos beállítódás (hexis) lesz a szükséges (bár föltehetőleg nem elégséges) feltétele (1181b9-11, e contrario).

Harmadszor: vizsgáljuk meg alaposabban, hogy mi ebben a passzusban a synesis sajátos szerepe. A megértés feladata itt a különbözö politikai közösségek törvényeinek összehasonlítása, s azután közülük a legjobb kiválasztása. Vagyis más, idegen (a miénktől eltérő) politikai gyakorlatok összevetése, annak érdekében, hogy megtaláljuk azt vagy ezeknek azt a kombinációját, amelyik a legjobban illeszkedik a mi politikai közösségünk sajátosságaihoz. ${ }^{47}$ Sajátnak és idegennek (oikeionnak és allotrionnak) az egymásra vonatkoztatása, a különböző politikai és jogi vélemények (doxák) közötti döntés és választás, mások (politikai) tapasztalatainak értő recipiálása és azután ezek alkalmazása a saját ügyekre, vagyis röviden mások politikai gyakorlatának megítélése - mindez jól illeszkedik ahhoz, amit Aristotelés a synesis kapcsán mond a Nikomachosi etika hatodik könyvéből a dolgozatom

\footnotetext{
${ }^{44}$ Vö. EN VI. 9. 1142a12-16, és P. A. Vander Waerdt: i. m. (43. jegyz.) a tapasztalat jelentőségéröl a phronésis kialakulásában és gyakorlásában.

${ }^{45}$ Vö. EN V. 13. 1137a11, ahol a synesis hasonló megfogalmazásban kerül elö, nevezetesen mint annak

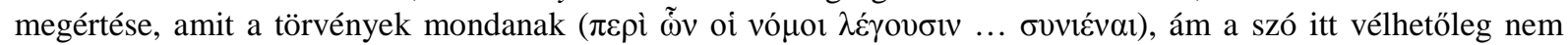
terminus értékủ. Mindazonáltal aligha véletlen, hogy Aristotelés itt is, nagyon hasonló szövegösszefüggésben, ugyanazt a szót használja.

${ }^{46}$ R. Bodéïs: i. m. (9. lj.) 105. Vö. EN VI. 8. 1141b24sk., politiké és nomothetiké viszonyáról; Pol. IV. 2. 1289a10-13, ahol a legjobb és a különböző kormányzati formákhoz is jól illeszkedő törvények fölismerése a phronésis feladata lesz. A phronimosról (a gyakorlatban jártas, bölcs emberről) mint törvényhozóról lásd $C$. $W$. Surprenant: Politics and Practical Wisdom: Rethinking Aristotle's Account of Phronesis" Topoi 31 (2012) 224226.

${ }^{47}$ Vö. Rh. I. 4. 1360a30-38, az etnográfiai és történeti ismeretek hasznosságáról a törvényhozás és a politikai tanácsadás számára. A kiválogatás és az összeillesztés eljárásának jelentőségére vonatkozóan Aristotelés egész gyakorlati filozófiai gondolkodása szempontjából lásd P. A. Vander Waerdt: i. m. (43. jegyz.); a synesis szerepéről ebben az eljárásban: 238. (Vö. Pol. IV. 1. 1288b21-1289a25; Rh. I. 8.)
} 
elején idézett szakaszban: „ahogyan a ‘tanulni’ szót ‘megérteni’ jelentésben használjuk akkor, amikor a tudományos tudást alkalmazzuk, úgy a megértés azt jelenti, hogy a véleményalkotást használjuk fel olyan kérdések megítélésére, amelyek a gyakorlati bölcsesség tárgyai, olyan esetekben, amikor valaki más beszél ezekről - mégpedig e kérdések helyes megítélésére

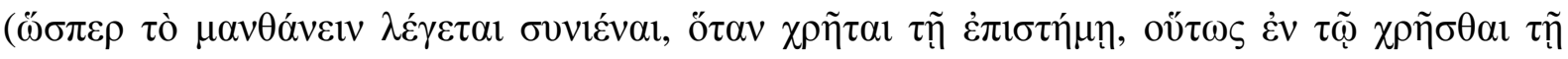

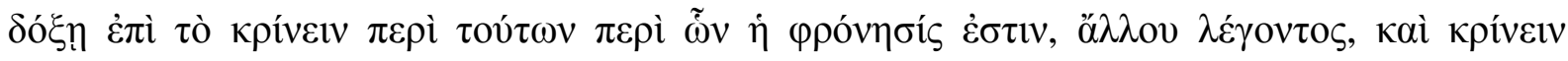

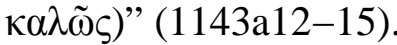

Végül negyedik érvként egy nyelvi-filológiai megfigyelés: a most elemzett szakasz

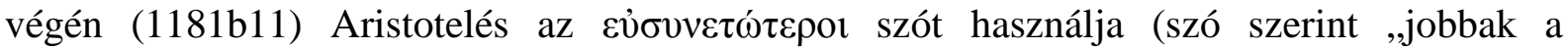
megértésben"), vagyis ugyanazt a szót, amely a dolgozatomban elsőként elemzett szakaszban

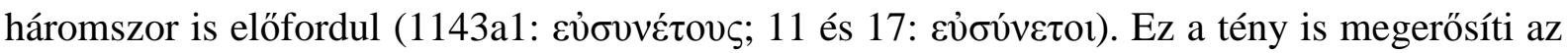
itt előadott értelmezést, amely szerint a synesis előfordulása a Nikomachosi etika tizedik könyvének végén távolról sem véletlenszerü, hanem konceptuális összefüggést jelez a fogalomnak a hatodik könyvben előadott kifejtésével.

A dolgozatomban utolsóként elemzendő szakasz a Politika negyedik könyvében található. Aristotelés itt a különböző kormányzati formákat a polis alkotórészeinek különböző kombinációira vezeti vissza (1290b21skk.). Ennek tárgyalása során, Platón vonatkozó nézeteinek kritikájából kiindulva (1291a10skk.) megállapítja a politikai közösség alkotórészeinek hierarchiáját. Érvelése szerint ahogyan a lélek egy élőlény fontosabb részének tekinthető, mint a test, úgy a politikai közösség esetében is különbséget kell tennünk a fontosabb és a kevésbé fontos részek között:

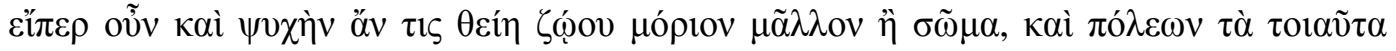

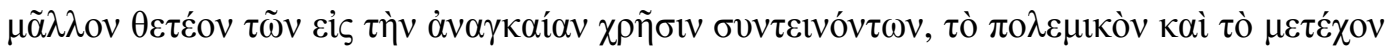

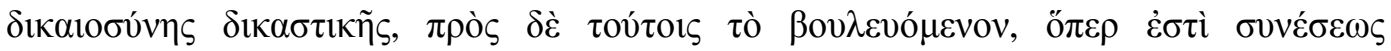

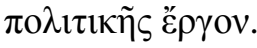

Ha tehát a lelket úgy fogjuk föl, mint amely fontosabb része az élölénynek, mint a test, akkor a városállam esetében is a szükségletek kielégítésére irányulókkal szemben az olyan részeket kell fontosabb alkotórészeknek tekintenünk, mint a katonáskodók osztálya vagy a bírósági igazságszolgáltatásban részt vevőké, továbbá a tanácskozó osztály, mert éppen ez [a tanácskozás, deliberáció] a politikai megértés feladata (Pol. IV. 4. 1291a24-28). 
Egyfelől a politiké synesis feladata (ergon) a buleuesthai, a megfontolás, a politikai

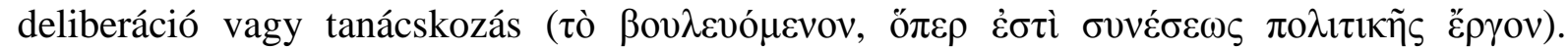
Másfelől az EN VI. 8. 1141b8-12 szerint a deliberáció a phronésis legfontosabb feladata. Így azután nem meglepö, ha a (politikai) deliberáció a Politikában a synesishez mint a phronésis egy dimenziójához kapcsolódik.

Ezen a ponton azonban fölmerül egy korábban már érintett kérdés. Miképpen lehet része a megértés (synesis) a megfontolásnak, sőt, hogyan lehet a megfontolás a politikai megértés sajátos munkája vagy müve (ergonja), ha egyszer a megfontolás döntéshez, elhatározáshoz (Aristotelés terminológiájában: proairesishez) vezet, miközben a megértés csak kritikai, nem pedig preskriptív? (Lásd erről a 15. jegyzetben és a hozzá tartozó föszövegben mondottakat.) Ezt a nehézséget annak alapján próbálom megoldani, amit Reeve mond a megértés és a megfontolás (mint a gyakorlati bölcsesség feladata) közötti viszonyról: „A megértést nem $\mathrm{X}$ alkalmazza akkor, amikor azt fontolja meg, hogy mit kellene tennie neki egy kétes helyzetben, hanem Y, amikor helyesen ítéli meg azt, hogy mit kellene tennie X-nek, és így képes lesz arra, hogy tanácsot adjon neki vagy kritizálja őt. Ha X és Y azonosak, vagyis ha egy cselekvő önmaga kritikusának vagy tanácsadójának szerepét tölti be, akkor ezzel úgyszólván valami megértés-szerü mutatkozik meg úgy, mint a gyakorlati bölcsesség egyik alkotórésze (...), mivel a megfontolás során alkalmazott gyakorlati bölcsesség azonos lesz a megértéssel akkor, amikor ez utóbbit egyszerüen annak megítélésére használjuk, hogy valakinek mit kell tennie."48 A második eset („Ha X és Y azonosak...”) analógnak látszik a politikai döntéshozatallal, amikor X és Y mondjuk a tanács tagjai és így (egymás számára) kritikusok és tanácsadók egyidejüleg. Megértik, értelmezik és értékelik, amit a másik személy mint polis-polgártárs mond, s a kölcsönös megértésnek és értékelésnek ez a dialogikus folyamata a közösségi deliberáció első szakaszának része lehet, amely deliberáció azután a cselekvést kijelölő döntéssel (határozattal) zárul. ${ }^{49}$

De mit jelent itt közelebbről a politikai deliberáció? Annak megfontolását, hogy egy adott helyzetben egy adott politikai közösség számára mi a legjobb, a leghasznosabb és a leghatékonyabb (vö. EN VI. 5. 1140b7-11, 8. 1141b23-29, 10. 1142b31-33; Rh. I. 2. 1357a1-4, 6. 1362a17-21; Pol. IV. 14. 1298a3skk. stb.). A Nikomachosi etika hatodik könyve szerint ennek meghatározása a phronésis feladata (EN VI. 5. 1140a25-30, b7-11; vö. Pol. III. 4. 1277a15, b25). A politikai cselekvés területén a helyes megfontolás a különböző

\footnotetext{
${ }^{48}$ C. D. C. Reeve: i. m. (6. jegyz.) 225.

${ }^{49}$ Vö. MM I. 34. 1197b12sk., ahol azt olvassuk, hogy valakiről azért mondják, hogy van synesise, mert képes a

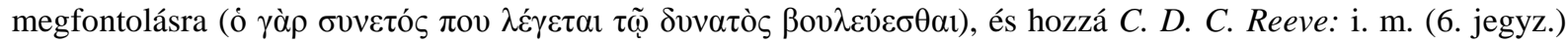
224 magyarázatát.
} 
egyéni megfontolásoknak valamiféle egybevetéséből vagy szintetizálásából áll (lásd Pol. IV. 15. 1286a26-35), s ezek a megfontolások különböző gyakorlatokat, eljárásokat és szabályokat foglalhatnak magukban. A dolog lényege ugyanaz, mint amit az imént tárgyalt szakaszban láttunk a törvények összevetésével kapcsolatban (EN X. 10. 1181a15-19), hiszen a phronésis politikai és jogi formái összekapcsolódnak, amennyiben a polis valamely ügyében hozott határozat a cselekvésre irányul: ez a deliberatív és egyszersmind legiszlatív folyamat utolsó eleme. A határozat tehát egy olyan törvényhozó eljárás eredményeként áll elő, amely magában foglalja a gyakorlati bölcsesség működését is. ${ }^{50}$ A megfontolást végzőknek egyfelől különböző véleményeket, érdekeket, egyéni megfontolásokat kell tekintetbe venniük, másfelől viszont azokat a törvényeket és eljárási szabályokat, amelyek a közösségi politikai akaratképzés döntéshozatali eljárását szabályozzák. Ennek a különböző doxák, bulésisek és nomosok polilógusából összeálló folyamatnak a végén pedig eredményre kell jutniuk, nevezetesen egy lehetőleg korrekt, méltányos és bölcs ítéletre vagy döntésre. Itt újra azok az elemek bukkannak föl, mint amelyeket a Nikomachosi etika hatodik könyvének a dolgozat első részében elemzett két passzusában láttunk (1142b34-1143a18 és 1143a19-32):

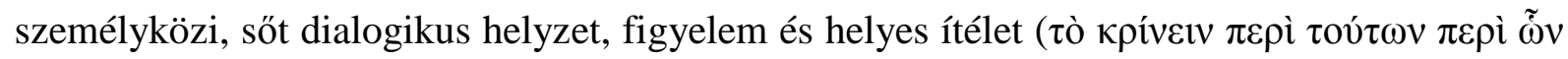

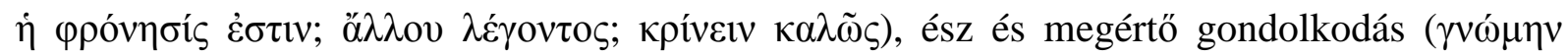

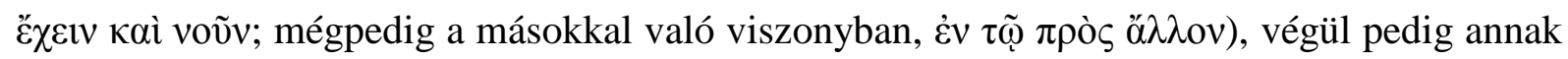

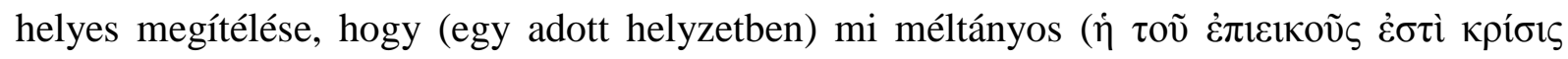

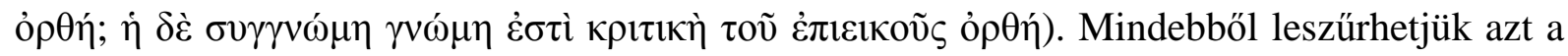
megállapítást, hogy a Politika fentebb idézett helyén a synesis szó (a politiké synesis szerkezetben) kifejezetten a phronésis politikai müködésére vonatkozik, s ezt a müködést a synesisben benne foglalt, egyszerre kognitív és emocionális beállítódás vezérli, amely képes a méltányos megértésre és a dialogikus megfontolásra, s képes arra, hogy tekintetbe vegyen társadalmi és politikai viszonyokat, eltérő véleményeket, érdekeket és döntéseket.

IV

Dolgozatom gondolatmenetét és legfontosabb eredményeit összefoglalva: a synesis és a vele rokon fogalmak, mint a gnómé és a syngnómé, a Nikomachosi etika hatodik könyvében személyközi viszonyokra vonatkoznak, s így egyszersmind az emberi élet társas és/vagy

\footnotetext{
${ }^{50}$ Lautner P.: i. m. (4. jegyz.) 29; vö. EN VI. 8. 1141b24-28.
} 
politikai közegére. A synesis tárgyai a személyközi viszonyok területén végbemenő cselekvéssel összefüggő kérdések. A synesis mint megértés a különböző nézőpontok, érdekek és helyzetek tekintetbe vételével a phronésis müködésének egy dimenziójáért felelős: a gyakorlati bölcsesség társas/társadalmi és politikai müködéséért. A synesis fogalmának ez a jelentése és funkciója a szó történetében gyökerezik, amennyiben e szó jelentéstartománya nem egyszerüen a személyközi viszonyt foglalja magában, hanem egymás megértésének sajátos, dialogikus módját is. Platónnál és Thukydidésnél találhatunk olyan helyeket, ahol a synesis gyakorlati, mi több, hangsúlyosan politikai képességeket foglal magában, és kifejezetten a vezető politikai képességére és politikai tudására is vonatkozik. A Nikomachosi etika nyolcadik könyvének egy helyén a synesis a társas viszonyok legelemibb formájának felfogását és megértését jelöli, ilyen módon pedig a szociális képességek első megnyilvánulásaként tarthatjuk számon. Abban a politikai és jogi kontextusban, amelyben a synesis a Nikomachosi etika tizedik könyvében elökerül, a megértés szerepet játszik sajátnak és idegennek (oikeionnak és allotrionnak) az egymásra vonatkoztatásában, a különbözö politikai és jogi doxák közötti döntésben, mások tapasztalatának értő átvételében és e tapasztalatok saját ügyeinkre alkalmazásában, röviden: mások politikai gyakorlatának megítélésében és alkalmazásában. Mindez összhangban van azzal az elemzéssel, amelyet Aristotelés ad a synesis fogalmáról a Nikomachosi etika hatodik könyvének a dolgozatom első részében idézett helyein. Végül pedig, a Politika legutóbb értelmezett passzusában a synesis szó (a politiké synesis szerkezet részeként) kifejezetten a phronésis politikai müködésére vonatkozik, s ezt a müködést a synesisben benne foglalt, egyszerre kognitív és emocionális beállítódás vezérli, amely képes a méltányos megértésre és a dialogikus megfontolásra, s képes arra, hogy tekintetbe vegyen társadalmi és politikai viszonyokat, eltérő véleményeket, érdekeket és döntéseket.

Simon Attila

Eötvös Loránd Tudományegyetem Összehasonlító Irodalom- és Kultúratudományi Tanszék simon_attila@hotmail.com 